\title{
Vitex agnus-castus: Botanical features and area, chemical composition of fruit, pharmacological properties, and medicinal uses
}

\author{
Grigory Vasilievich Adamov ${ }^{*}$ (D), Tamara Danilovna Rendyuk², Olga Leonidovna Saybel³, Tamara Darizhapovna Dargaeva³ \\ Andrey Nikolaevich Tsitsilin ${ }^{4}$, Dmitry Olegovich Bokov² \\ ${ }^{1}$ Laboratory of Atomic-Molecular Bioregulation and Selection, All-Russian Scientific Research Institute of Medicinal and Aromatic Plants, Moscow, Russia. \\ ${ }^{2}$ Institute of Pharmacy, Sechenov First Moscow State Medical University Sechenov University, Moscow, Russia. \\ ${ }^{3}$ Center for Chemistry and Pharmaceutical Technology, All-Russian Scientific Research Institute of Medicinal and Aromatic Plants, Moscow, Russia. \\ ${ }^{4}$ Laboratory of the Botanical Garden, All-Russian Scientific Research Institute of Medicinal and Aromatic Plants, Moscow, Russia.
}

\section{ARTICLE INFO \\ Received on: 02/06/2021 \\ Accepted on: 24/11/2021 \\ Available Online: 05/03/2022}

\section{Key words:}

Vitex agnus-castus L.,

biologically active substances, fruits, premenstrual

syndrome, pharmacologic

properties.

\begin{abstract}
This review is based on published data on the fruits of the chaste tree (Vitex agnus-castus L.), a traditional medicinal plant used to treat premenstrual syndrome (PMS). The review summarizes and analyzes the existing literature on the chemical composition and pharmacological properties of the fruit extract and its individual chemical compounds. According to the current data, the presence of 20 flavonoids, 10 iridoids, 11 phenolic acids, three diterpene alkaloids, and 12 terpenes was confirmed in the extract of Vitex fruits. Many of these compounds exhibit pharmacological activity according to the results of preclinical studies. Thus, various authors have confirmed the presence of dopaminergic, opioid, estrogenic, immunomodulatory, antineoplastic, and antioxidant activity. It is assumed that the cumulative effect of several chemical compounds also has beneficial effects on the complex regulation of the female reproductive system. In this review, special attention is paid to data obtained from clinical trials because they are the most important and reliable studies of drug efficacy and safety. Nine clinical studies that examined the effect of preparations based on chaste tree fruit extract on the female reproductive system are reviewed. Studies have shown that the fruits of the chaste tree significantly reduce the symptoms of PMS, normalize the menstrual cycle, and lower prolactin levels. The use of Vitex is often preferable due to its high efficacy, long-term and short-term tolerance, and positive effect on the female reproductive system, including fertility.
\end{abstract}

\section{INTRODUCTION}

At the pharmaceutical industry's present stage of development, plants are one of the most important sources of biologically active substances. The diversity of plant species results in significant variations in the number of biosynthetic pathways that enable plants to produce hundreds of thousands of different chemical compounds. Total plant extracts are of great interest to researchers, as evidenced by the volume of studies in

"Corresponding Author

Grigory Vasilievich Adamov, Laboratory of Atomic-Molecular Bioregulation and Selection, All-Russian Scientific Research Institute of Medicinal and Aromatic Plants, Moscow, Russia.E-mail: adamov@vilarnii.ru this field (Aleshnikova et al., 2020; Palvinskiy et al., 2020; Pisarev et al., 2020; Rogozhnikova et al., 2020).

As a rule, herbal medicines are safer than newly synthesized substances due to years of experience gained from their use in folk and traditional medicine in different countries. Human metabolism has evolutionarily adapted to interaction with plant compounds, and in most cases, the excretory system successfully removes them from the body without disrupting homeostasis.

Modern trends in pharmaceutical science in the field of phytochemistry are aimed at finding new sources of bioactive substances, developing methods for extracting them from plant materials, and converting them into drugs. In gynecological practice, plant-based medicines are used to impart relief from the undesirable manifestations of premenstrual syndrome (PMS), correct menstrual irregularities, and prevent metabolic disorders in 
menopause. One of the sources of such medications is the chaste tree (also called Vitex, Abraham's balm, monk's pepper, or lilac chaste tree).

The chaste tree (Vitex agnus-castus L.) is a low tree or tall shrub that grows to a height of 3-6 $\mathrm{m}$. The modern taxonomy of plants classifies it as a member of the Lamiaceae family, but it previously belonged to the Verbenaceae family. It grows along riverbanks and seacoasts as a wild plant in the Mediterranean region (Southern Europe, North Africa, and Western Asia) and the Caucasus. In Russia, it is found on the coastal pebble beaches of the Caucasus Black Sea; in Crimea, it is a wild plant (Fedorov et al., 1978). In Russia, Vitex is cultivated in limited areas in the North Caucasus, and the fruits are used as a raw material for the production of dietary supplements. At present, V. agnus-castus grows on the East, South, and West Coasts of the United States (United States Department of Agriculture, 2021). It is also found in northeastern India (Nadkarni et al., 1954), Afghanistan and Pakistan (Flora of Pakistan), and Iran (Abbas Azimi et al., 2006; Salehpour et al., 2018).

It has been speculated that another species of chaste tree grows in India, namely, Vitex pseudonegundo (Hausskn.) Hand.-Mazz. ( $V$. agnus-castus var. pseudo-negundo Hausskn.). However, modern taxonomy considers these taxa synonyms of $V$. agnus-castus L. even though they differ from each other not only in area but also in several morphological and anatomical features as well as levels of bioactive substances, especially essential oil components. The fruits of this plant are widely used in traditional systems of medicine in different countries for the mitigation of PMS symptoms, improvement of the psychoemotional state of women, and normalization of the menstrual cycle. In addition, they serve as a raw material for medicines. The chaste tree is also included in pharmacopoeias in Europe, including Great Britain, and the USA.

Researchers from different countries have isolated individual compounds from chaste tree fruits, the pharmacological properties of which have been studied both in vivo and in vitro. However, these studies did not establish the exact and complete mechanism of action of these compounds on the female reproductive system.

In this regard, this review aimed at searching for relevant information about chaste tree fruits to understand their effects on the hormonal regulation of the female reproductive system.

\section{Botanical Description of the Chaste Tree}

Modern plant taxonomy indicates that the genus Vitex comprises 223 species (ThePlantList, 2013). Vitex agnus-castus L. is a low tree or tall shrub 3-6 $\mathrm{m}$ in height (Fig. 1). It occurs in the form of a low, erect shrub or as a prostrate creeping habit at a height below $1 \mathrm{~m}$. The bark of old trunks is light gray with a barely noticeable pink tint, cracking into approximately regular rectangles with the edges bent upwards. The young shoots are slightly tetrahedral and gray. The leaves, which comprise 3-7 leaflets, are thin, opposite, palmate, $8-12 \mathrm{~cm}$ long, and 12-14 $\mathrm{cm}$ wide, with white tomentum on the lower surface. The inflorescence is paniculate, terminal, or axillary, 15-20 cm long, and $6-8 \mathrm{~cm}$ wide. The flowers are numerous, up to $0.8-1.0 \mathrm{~cm}$ long and $0.3-0.4 \mathrm{~cm}$ wide, and massed in airy half-umbrellas. The calyx is campanulate, $0.2-0.3 \mathrm{~cm}$ long, three times shorter than the corolla, densely hairy, and sometimes even woolly, with rounded, slightly wavy teeth along the edges. The corolla is bilabiate, with a two-incised upper lip and a three-incised lower lip. The color of the petals ranges from pale pink, pink, dark pink, and lilac to purple and occasionally white.

The lobes on the inner side of the lower lip at the point of attachment of the stamens are hairy. In the middle lobe, which is much larger than the other two, patches of long shaggy hairs reach the base of the incision. The pistil and four stamens exceed the corolla, and the ovary is round and up to $0.1 \mathrm{~cm}$ in diameter. The fruit is round and dark brown or black in color, with a blue bloom and shiny drupe; it is $3-4 \mathrm{~mm}$ in diameter and almost entirely covered with a woolly calyx. In appearance, the fruits of the prutnyak resemble black pepper and often serve as its substitute due to their spicy taste. The fruits bloom from June to October and ripen between October and November but remain on the tree from December to January (Karaguzel et al., 2009; Mammadova et al., 2019). Previously, varieties and forms of the chaste tree were distinguished based on flower color and size as well as the degree of dissection and serration of the leaf blade. However, in modern taxonomy, all old infraspecies ranks are considered synonymous to $V$. agnus-castus L.

\section{Chemical Composition}

The fruits of the chaste tree contain several secondary metabolites: terpenoids (the main components of the essential oil), flavonoids, iridoids, and phenol carboxylic acids (Fig. 2). More

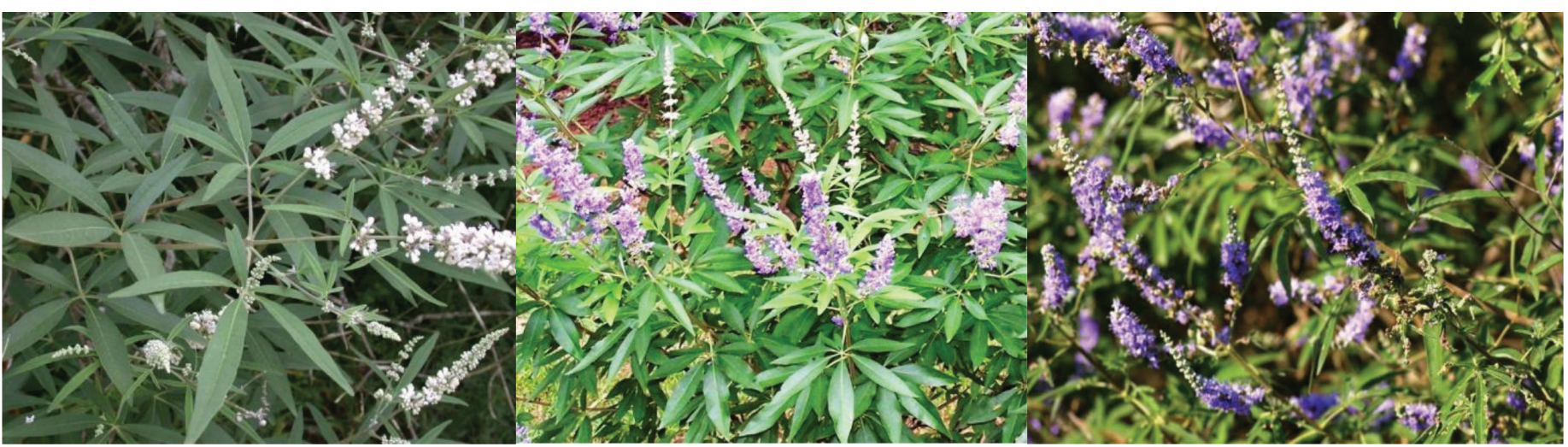

Figure 1. Blooming chaste tree. 


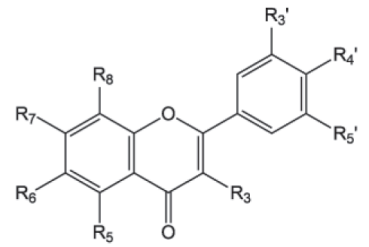

1. $\mathrm{R}_{3}-\mathrm{OMe}, \mathrm{R}_{5}-\mathrm{OH}, \mathrm{R}_{6}-\mathrm{OMe}, \mathrm{R}_{7}-\mathrm{OMe}, \mathrm{R}_{8}-\mathrm{H}, \mathrm{R}_{3^{\prime}}-\mathrm{OH}, \mathrm{R}_{4^{\prime}}-\mathrm{OMe}, \mathrm{R}_{5^{\prime}}-\mathrm{H}$.

2. $\mathrm{R}_{3}-\mathrm{H}, \mathrm{R}_{5}-\mathrm{OH}, \mathrm{R}_{6}-\mathrm{H}, \mathrm{R}_{7}-\mathrm{OH}, \mathrm{R}_{8}-\mathrm{H}, \mathrm{R}_{3^{\prime}}-\mathrm{OH}, \mathrm{R}_{4^{\prime}}-\mathrm{OH}, \mathrm{R}_{5^{\prime}}-\mathrm{H}$.

3. $\mathrm{R}_{3}-\mathrm{H}, \mathrm{R}_{5}-\mathrm{OH}, \mathrm{R}_{6}-\mathrm{H}, \mathrm{R}_{7}-\mathrm{OGlu}, \mathrm{R}_{8}-\mathrm{H}, \mathrm{R}_{3^{\prime}}-\mathrm{OH}, \mathrm{R}_{4^{\prime}}-\mathrm{OH}, \mathrm{R}_{5^{\prime}}-\mathrm{H}$.

4. $\mathrm{R}_{3}-\mathrm{OH}, \mathrm{R}_{5}-\mathrm{OH}, \mathrm{R}_{6}-\mathrm{OMe}, \mathrm{R}_{7^{-}} \mathrm{OMe}, \mathrm{R}_{8}-\mathrm{H}, \mathrm{R}_{3^{\prime}} \mathrm{OH}, \mathrm{R}_{4^{\prime}}-\mathrm{OMe}, \mathrm{R}_{5^{\prime}}-\mathrm{H}$.

5. $\mathrm{R}_{3}-\mathrm{OMe}, \mathrm{R}_{5}-\mathrm{OH}, \mathrm{R}_{6}-\mathrm{H}, \mathrm{R}_{7}-\mathrm{OMe}, \mathrm{R}_{8^{-}}, \mathrm{R}_{3^{\prime}}-\mathrm{OH}, \mathrm{R}_{4^{\prime}}-\mathrm{OH}, \mathrm{R}_{5^{\prime}}-\mathrm{H}$.

6. $\mathrm{R}_{3}-\mathrm{OMe}, \mathrm{R}_{5}-\mathrm{OH}, \mathrm{R}_{6}-\mathrm{OH}, \mathrm{R}_{7}-\mathrm{H}, \mathrm{R}_{8}-\mathrm{H}, \mathrm{R}_{3^{\prime}}-\mathrm{H}, \mathrm{R}_{4^{\prime}}-\mathrm{OH}, \mathrm{R}_{5^{\prime}}-\mathrm{H}$.

7. $\mathrm{R}_{3}-\mathrm{OH}, \mathrm{R}_{5}-\mathrm{OMe}, \mathrm{R}_{6}-\mathrm{OMe}, \mathrm{R}_{7}-\mathrm{OMe}, \mathrm{R}_{8}-\mathrm{H}, \mathrm{R}_{3^{\prime}}-\mathrm{H}, \mathrm{R}_{4^{\prime}}-\mathrm{OMe}, \mathrm{R}_{5^{\prime}}-\mathrm{H}$.

8. $\mathrm{R}_{3}-\mathrm{OMe}, \mathrm{R}_{5}-\mathrm{OH}, \mathrm{R}_{6}-\mathrm{H}, \mathrm{R}_{7}-\mathrm{OH}, \mathrm{R}_{8}-\mathrm{H}, \mathrm{R}_{3^{\prime}}-\mathrm{OH}, \mathrm{R}_{4^{\prime}}-\mathrm{OH}, \mathrm{R}_{5^{\prime}}-\mathrm{H}$.

9. $\mathrm{R}_{3}-\mathrm{OMe}, \mathrm{R}_{5}-\mathrm{OH}, \mathrm{R}_{6}-\mathrm{H}, \mathrm{R}_{7}-\mathrm{OH}, \mathrm{R}_{8}-\mathrm{H}, \mathrm{R}_{3^{\prime}}-\mathrm{H}, \mathrm{R}_{4^{\prime}}-\mathrm{OH}, \mathrm{R}_{5^{\prime}}-\mathrm{H}$.

10. $\mathrm{R}_{3}-\mathrm{H}, \mathrm{R}_{5}-\mathrm{OH}, \mathrm{R}_{6}-\mathrm{H}, \mathrm{R}_{7}-\mathrm{OH}, \mathrm{R}_{8}-\mathrm{H}, \mathrm{R}_{3^{\prime}}-\mathrm{H}, \mathrm{R}_{4^{\prime}}-\mathrm{OH}, \mathrm{R}_{5^{\prime}}-\mathrm{H}$.

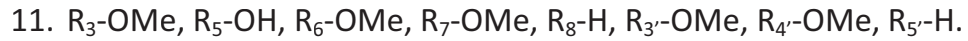

12. $\mathrm{R}_{3}-\mathrm{H}, \mathrm{R}_{5}-\mathrm{OH}, \mathrm{R}_{6}-\mathrm{H}, \mathrm{R}_{7}-\mathrm{OH}, \mathrm{R}_{8}-\mathrm{Glu}, \mathrm{R}_{3^{\prime}}-\mathrm{H}, \mathrm{R}_{4^{\prime}}-\mathrm{OH}, \mathrm{R}_{5^{\prime}}-\mathrm{H}$.

13. $\mathrm{R}_{3}-\mathrm{H}, \mathrm{R}_{5}-\mathrm{OH}, \mathrm{R}_{6}-\mathrm{H}, \mathrm{R}_{7}-\mathrm{OH}, \mathrm{R}_{8}-\mathrm{Glu}, \mathrm{R}_{3^{\prime}}-\mathrm{OH}, \mathrm{R}_{4^{\prime}}-\mathrm{OH}, \mathrm{R}_{5^{\prime}}-\mathrm{H}$.

14. $\mathrm{R}_{3}-\mathrm{H}, \mathrm{R}_{5}-\mathrm{OH}, \mathrm{R}_{6}-\mathrm{Glu}, \mathrm{R}_{7}-\mathrm{OH}, \mathrm{R}_{8}-\mathrm{H}, \mathrm{R}_{3^{\prime}}-\mathrm{H}, \mathrm{R}_{4^{\prime}}-\mathrm{OH}, \mathrm{R}_{5^{\prime}}-\mathrm{H}$.

15. $\mathrm{R}_{3}-\mathrm{H}, \mathrm{R}_{5}-\mathrm{OH}, \mathrm{R}_{6}-\mathrm{Glu}, \mathrm{R}_{7}-\mathrm{OH}, \mathrm{R}_{8}-\mathrm{H}, \mathrm{R}_{3^{\prime}}-\mathrm{OH}, \mathrm{R}_{4^{\prime}}-\mathrm{OH}, \mathrm{R}_{5^{\prime}}-\mathrm{H}$.

16. $\mathrm{R}_{3}-\mathrm{OH}, \mathrm{R}_{5}-\mathrm{OH}, \mathrm{R}_{6}-\mathrm{H}, \mathrm{R}_{7}-\mathrm{OH}, \mathrm{R}_{8}-\mathrm{H}, \mathrm{R}_{3^{\prime}}-\mathrm{H}, \mathrm{R}_{4^{\prime}}-\mathrm{OH}, \mathrm{R}_{5^{\prime}}-\mathrm{H}$.

17. $\mathrm{R}_{3}-\mathrm{OMe}, \mathrm{R}_{5}-\mathrm{OH}, \mathrm{R}_{6}-\mathrm{OMe}, \mathrm{R}_{7}-\mathrm{OMe}, \mathrm{R}_{8}-\mathrm{H}, \mathrm{R}_{3^{\prime}}-\mathrm{H}, \mathrm{R}_{4^{\prime}}-\mathrm{OH}, \mathrm{R}_{5^{\prime}}-\mathrm{H}$.

18. $\mathrm{R}_{3}-\mathrm{H}, \mathrm{R}_{5}-\mathrm{OH}, \mathrm{R}_{6}-\mathrm{OMe}, \mathrm{R}_{7}-\mathrm{OMe}, \mathrm{R}_{8}-\mathrm{H}, \mathrm{R}_{3^{\prime}}-\mathrm{OH}, \mathrm{R}_{4^{\prime}}-\mathrm{OMe}, \mathrm{R}_{5^{\prime}}-\mathrm{H}$.<smiles>[R3]c1cc([R3])cc(C2Oc3c([R])c([R])c([R])c([R9])c3C(=O)C2[R9])c1</smiles>

19. $\mathrm{R}_{3}-\mathrm{H}, \mathrm{R}_{5}-\mathrm{OH}, \mathrm{R}_{6}-\mathrm{H}, \mathrm{R}_{7} \mathrm{OMe}, \mathrm{R}_{8}-\mathrm{H}, \mathrm{R}_{3^{\prime}}-\mathrm{OH}, \mathrm{R}_{4^{\prime}}-\mathrm{OH}, \mathrm{R}_{5^{\prime}}-\mathrm{OH}$.

20. $\mathrm{R}_{3}-\mathrm{H}, \mathrm{R}_{5^{-}} \mathrm{OH}, \mathrm{R}_{6}-\mathrm{H}, \mathrm{R}_{7}-\mathrm{OH}, \mathrm{R}_{8^{-}}, \mathrm{R}_{3^{\prime}}-\mathrm{OH}, \mathrm{R}_{4^{\prime}}-\mathrm{H}, \mathrm{R}_{5^{\prime}}-\mathrm{OH}$.
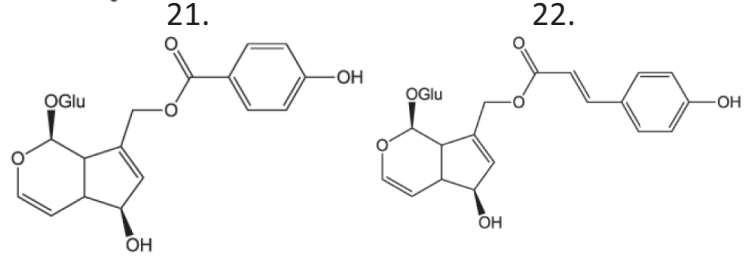

23.

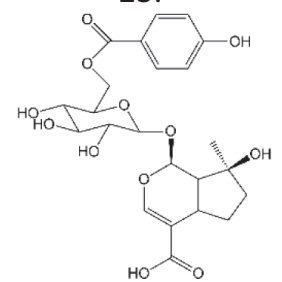

25.

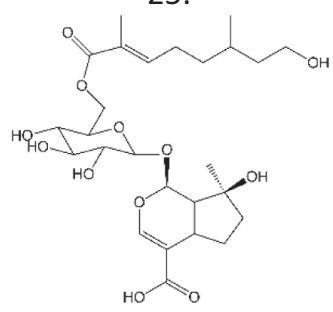

29.

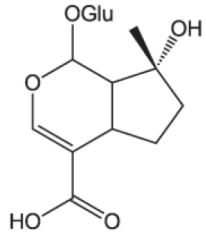

33.<smiles>COc1cc(C(=O)O)ccc1O</smiles>

26.

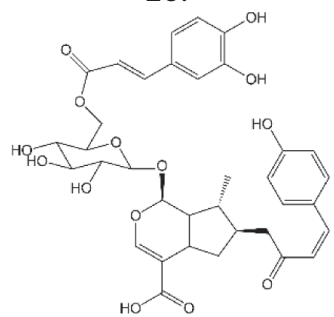

30.

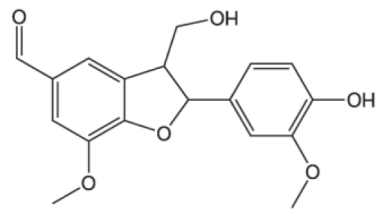

34.

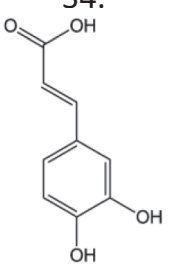

27.

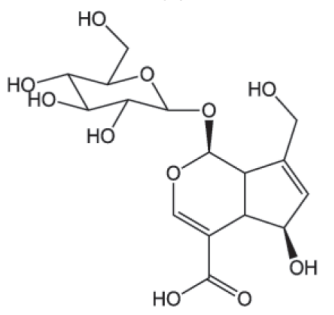

31.<smiles>O=C(O)c1ccc(O)c(O)c1</smiles>

35.

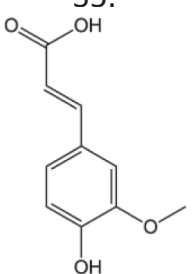

24.

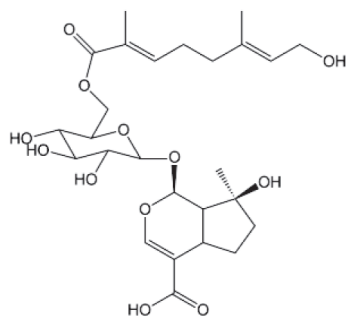

28.

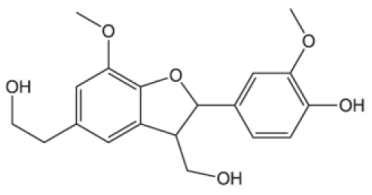

32.<smiles>COc1ccc(O)c(C(=O)O)c1</smiles>

36.<smiles>O=C(O)c1ccc(O)cc1</smiles>

Figure 2. Compounds chaste tree. 
<smiles>O=C(/C=C\c1ccc(O)cc1)OCCc1ccc(O)cc1</smiles>

41.<smiles>COC(=O)c1ccc(O)c(O)c1</smiles>

45.<smiles>C=CC(C)(O)CCC1(C)C2=C(C(OC(C)=O)C(OC(=C)C)C1C)C(C)(C)CCC2</smiles>

49.

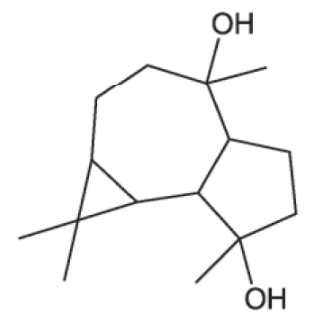

53.

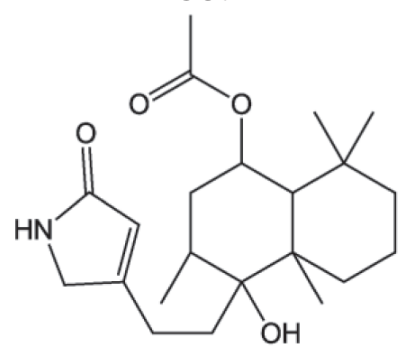

38.<smiles>COc1cc(CCC(=O)O)ccc1O</smiles>

42.<smiles></smiles>

46.<smiles>CC(=O)OC1CC(C)C2(O)CCc3ccoc3CC2(C)C1C(C)(C)C</smiles>

50.<smiles>CC1CCC2(C(=O)O)CCC3(C)C(=CCC4C5CCC6C(C)(C)C(O)C(O)CC6(C)C5CCC43C)C2C1C</smiles>

54.<smiles></smiles>

39.<smiles>O=C(/C=C/c1ccc(O)c(O)c1)OC1CC(O)(C(=O)O)CC(O)C1O</smiles>

43.<smiles>CC(=O)OC1CC2C(C1)C(C)(CCc1ccoc1)C1C(C)(C)CCCC21C</smiles>

47.<smiles>C=C1CCC2C(C3C1CCC3(C)O)C2(C)C</smiles>

51.<smiles>CC1(C)CCC2(C(=O)O)CCC3(C)C(=CCC4C5(C)CC(O)C(O)C(C)(C)C5CCC43C)C2C1</smiles>
55.<smiles></smiles>

40.<smiles>COC(=O)c1ccc(OC)c(O)c1</smiles>

44.<smiles>C=C1C(C)CCC2(C)C1CCC1CC=C(C3=CC(=O)OC3)CC12O</smiles>

48.<smiles>C=CC1(C)CCC2C(C)(CCC3C(C)(C)CCCC32C)O1</smiles>

52.

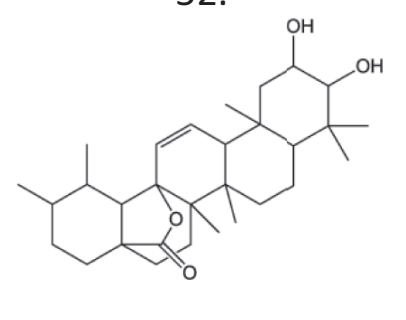

Figure 2. Compounds chaste tree. 
than 60 substances have been identified in chaste tree fruits using chromatographic and spectral methods.

Flavonoids and iridoids predominate in chaste tree fruits in terms of the contents and amounts of compounds present. The dominant flavonoids are casticin and luteolin-7-glycoside. The other compounds present are luteolin, 3,3'-dihydroxy-5,6,7,4'-tetramethoxyflavone, 3,7-dimethylquercetin, 3-O-methylkaempferol, 3-hydroxy5,6,7,4-tetramethoxyflavone, 3-methylquercetin, 3-methylkaempferol, 5,3',5'-trihydroxymethoxyflavanone, 5,7,3',5'-tetrahydroxyflavanone, apigenin, artemetin, vitexin, orientin, isovitexin, isoorientin, kaempferol, penduletin, and eupatorin (Chen et al., 2011; Choudhary et al., 2009; Hajdú et al., 2007; Makhmoor and Choudhary, 2010; Mari et al., 2015; Sogame et al., 2019; Sorensen and Katsiotis, 1999).

Agnuside is the dominant iridoid of the chaste tree. The other iridoids are 10-p-coumaroylaucubin (eurostoside), 6'-O-p-hydroxybenzoylmussaenosidic acid, agnucastoside $\mathrm{A}$, agnucastoside $\mathrm{B}$, agnucastoside $\mathrm{C}$, aucubin, vladirol $\mathrm{F}$, mussaenosidic acid, and ficusal (Fukahori et al., 2014; Görler et al., 1985; Kuruüzüm-Uz et al., 2003; Li et al., 2013).

Some other compounds with phenolic structure have been identified. These are 3,4-dihydroxybenzoic acid, 5-hydroxy2-methoxybenzoic acid, vanillic acid, caffeic acid, ferulic acid, $p$-hydroxybenzoic acid, $p$-hydroxyphenylethanol-p-coumarate, myzodendrone, chlorogenic acid, methylisovanillate, and methyl 3,4-dihydroxybenzoate (Chen et al., 2011; Choudhary et al., 2009; Kuruüzüm-Uz et al., 2003; Li et al., 2013; Makhmoor and Choudhary, 2010; Şarer et al., 2008; Sogame et al., 2019).

The following terpenoid compounds are present in the lipophilic fraction: vitexilactone, vitexilactone $\mathrm{B}$, vitetrifoline C, vitetrifoline D, vitetrifoline I, rotundifuran, spatulenol, 8-epimanoyl oxide, aromadendren- $4 \alpha, 10 \alpha$-diol, 3-epi-corosolic acid, 3-epi-maslinic acid, and ilelatifol D (Chen et al., 2011; Hajdú et al., 2007; Li et al., 2013; Şarer et al., 2008).

The diterpene alkaloids vitexilactam A, vitexilactam B, and vitexilactam $\mathrm{C}$ are unique to chaste tree fruits (Li et al., 2002, 2013). The identified compounds are listed in Table 1.

The pharmacological properties of many medicinal plants are conferred by their essential oils. In view of the specific nature of their study, medical uses, and physical and chemical properties as well as their characteristic production technologies, it is advisable to present data on essential oils separately.

The composition of the essential oil extracted from chaste tree fruits has been well studied and comprises mainly terpenoid compounds. The most common and informative method for studying the qualitative and quantitative composition of essential oils is gas chromatography coupled to a mass detector. Published data indicate that the following compounds have been identified in the essential oil of mature, air-dried chaste tree fruits using distillation with water vapor: $\alpha$-pinene, sabinene, $\beta$-pinene, $\beta$-myrcene, $p$-cymene, limonene, 1,8-cineole, cis-sabinene hydrate, trans-sabinene hydrate, cis- $p$-ment-2-en-1-ol, trans- $p$-ment-2en-1-ol, trans-verbenol, $\delta$-terpineol, terpinene-4-ol, krypton, $\alpha$-terpineol, trans-carveol, $\beta$-citronelol, and $\alpha$-terpinyl acetate. The other compounds are trans- $\beta$-caryophyllene, trans- $\alpha$-bergamotene, cis- $\beta$-farnesene, trans- $\beta$-farnesene, dihydroaromadendren, curcumen, viridiflorene, $\beta$-bisabolene, $\beta$-basanene, myristicin, palustrol, spatulenol, caryophyllene oxide, iceol, humulene epoxide II, $\tau$-cadinol, 14-hydroxy-cis-caryophyllene, epi- $\alpha$ bisabolol, trans-isovalencenol, cubiten, (3E)-cembrene A, sklaren, (E, Z)-geranyllinalool, (Z, E)-geranyllinalool, abietatriene, and 13-epimanool (Ghannadi et al., 2012; Sorensen and Katsiotis, 2000; Stojković et al., 2011).

The relative proportions of the components of the essential oil vary depending on the place of growth, phenotypic characteristics, and duration of the distillation process used for obtaining the oil. Studies have shown that prolonged distillation resulted in a product containing greater amounts of low-volatile components but thermolabile compounds were degraded. The content variability levels for the main components have been experimentally established: sabinene $(16.4 \%-44.1 \%), 1,8$-cineole $(8.4 \%-15.2 \%), \quad \beta$-caryophyllene $(2.1 \%-5.0 \%)$, and trans- $\beta$ farnesene $(5.0 \%-11.7 \%)$ (Sorensen and Katsiotis, 2000).

\section{Preclinical Studies}

Currently, the mechanism by which chaste tree products affect the female reproductive system is not fully understood. However, studies have shown that bioactive substances contained in the chaste tree exert dopaminergic, opioid, and estrogenic effects (Rafieian-Kopaei and Movahedi, 2017). Moreover, the extant literature confirms the antioxidant, immunomodulatory, and antitumor effects of the chaste tree and its individual bioactive components.

\section{Dopaminergic effects}

A decrease in dopamine secretion in females, such as under conditions of chronic stress, may lead to an increase in blood prolactin content, which in turn contributes to the occurrence of proliferative changes in the mammary gland and mastodynia. It also results in insufficiency of the luteal phase, thereby leading to infertility. Chaste tree compounds reduce the blood level of prolactin and decrease its negative manifestations by activating the dopamine receptors of the pituitary gland. These properties of chaste tree extracts (whole extract, fractions, and individual bioactive compounds) were revealed via in vitro experiments and confirmed in clinical studies.

Sliutz et al. (1993) found that the release of prolactin by cells of the pituitary gland in rats was significantly inhibited by the whole extract of chaste tree fruits. A similar effect on these cells was achieved by the action of synthetic agonists of the dopamine receptors. The binding of components of the ethanol extract of the chaste tree to various receptors (D2-dopamine, H1histamine, benzodiazepine, opioid receptors, and the binding site of the serotonin transporter) was studied in detail (Meier et al., 2000) using the radioligand method based on the assessment of the concentration of half-maximal binding $\left(\mathrm{IC}_{50}\right)$. The results showed that the whole extract exhibited dopaminergic activity $\left(\mathrm{IC}_{50}=52\right.$ $\mu \mathrm{g} / \mathrm{ml}$ ), with the hexane fraction of the extract being more active $\left(\mathrm{IC}_{50}=32 \mu \mathrm{g} / \mathrm{ml}\right.$ ). A study of BNO 1095 (a commercial preparation based on chaste tree extract) that investigated the pharmacological effects of chromatographic eluates found that the active principles involved in dopaminergic activity were bicyclic terpenoids, mainly clerodane, rotundifuran, and $6 \beta, 7 \beta$-diacetoxy-13-hydroxylabda-8, 14-diene. There was no binding to the histamine receptor, benzodiazepine receptor, or histamine transporter. 
Table 1. Bioactive substances identified in chaste tree fruits.

\begin{tabular}{|c|c|c|c|}
\hline & Name & CAS number & Source \\
\hline \multicolumn{4}{|c|}{ Flavonoids } \\
\hline 1 & Casticin & $479-91-4$ & (Chen et al., 2011) \\
\hline 2 & Luteolin & $491-70-1$ & (Chen et al., 2011) \\
\hline 3 & Luteolin-7-glycoside & $5373-11-5$ & (Mari et al., 2015) \\
\hline 4 & 3,3'-dihydroxy-5,6,7,4'-tetramethoxyflavone & & (Choudhary et al., 2009) \\
\hline 5 & 3,7-dimethylquercetin & $2068-02-2$ & (Chen et al., 2011) \\
\hline 6 & 3-O-metyl kaempferol & & (Chen et al., 2011) \\
\hline 7 & 3-hydroxy-5,6,7,4' -tetramethoxyflavone & 21764-09-0 & (Makhmoor et al., 2010) \\
\hline 8 & 3-methylquercetin & $1486-70-0$ & (Chen et al., 2011) \\
\hline 9 & 3-metyl kaempferol & $1592-70-7$ & (Chen et al., 2011) \\
\hline 10 & Apigenin & $520-36-5$ & (Chen et al., 2011) \\
\hline 11 & Artemetin & $479-90-3$ & (Choudhary et al., 2009) \\
\hline 12 & Vitexin & $3681-93-4$ & (Hajdú et al., 2007) \\
\hline 13 & Orientin & $28608-75-5$ & (Hajdú et al., 2007) \\
\hline 14 & Isovitexin & $38953-85-4$ & (Mari et al., 2015) \\
\hline 15 & Isoorientin & $4261-42-1$ & (Fukahori et al., 2014) \\
\hline 16 & Kaempferol & $520-18-3$ & (Chen et al., 2011) \\
\hline 17 & Penduletin & $569-80-2$ & (Makhmoor et al., 2010) \\
\hline 18 & Eupatorin & $855-96-9$ & (Hajdú et al., 2007) \\
\hline 19 & $5,3^{\prime}, 5^{\prime}$-trihydroxymetoxyflavanone & & (Chen et al., 2011) \\
\hline 20 & $5,7,3^{\prime}, 5^{\prime}$-tetrahydroxyflavanone & & (Chen et al., 2011) \\
\hline \multicolumn{4}{|c|}{ Iridoids } \\
\hline 21 & Agnuside & $1027-63-7$ & (Kuruüzüm-Uz et al., 2003) \\
\hline 22 & 10-p-coumaroyl aucubin (eurostoside) & $85802-33-1$ & (Kuruüzüm-Uz et al., 2003) \\
\hline 23 & 6'-O-p-hydroxybenzoilmussaenosidic acid & $87667-61-6$ & (Kuruüzüm-Uz et al., 2003) \\
\hline 24 & Agnucastoside A & & (Kuruüzüm-Uz et al., 2003) \\
\hline 25 & Agnucastoside B & & (Kuruüzüm-Uz et al., 2003) \\
\hline 26 & Agnucastoside $\mathrm{C}$ & & (Kuruüzüm-Uz et al., 2003) \\
\hline 27 & Aucubin & $479-98-1$ & (Kuruüzüm-Uz et al., 2003) \\
\hline 28 & Vladirol F & & (Chen et al., 2011) \\
\hline 29 & Mussaenosidic acid & $82451-22-7$ & (Kuruüzüm-Uz et al., 2003) \\
\hline 30 & Ficusal & $321991-55-3$ & (Chen et al., 2011) \\
\hline \multicolumn{4}{|c|}{ Phenolic acids } \\
\hline 31 & 3,4-dihydroxybenzoic acid & $99-50-3$ & (Choudhary et al., 2009) \\
\hline 32 & 5-hydroxy-2-metoxybenzoic acid & $2612-02-4$ & (Choudhary et al., 2009) \\
\hline 33 & Vanilic acid & $121-34-6$ & (Choudhary et al., 2009) \\
\hline 34 & Caffeic acid & $331-39-5$ & (Şarer et al., 2008) \\
\hline 35 & Ferulic acid & $1135-24-6$ & (Chen et al., 2011) \\
\hline 36 & $p$-hydroxybenzoic acid & $99-96-7$ & $\begin{array}{l}\text { (Makhmoor et al., 2010; } \\
\text { Choudhary et al., 2009) }\end{array}$ \\
\hline 37 & $p$-hydroxy phenyl ethanol-p-coumarate & & (Chen et al., 2011) \\
\hline 38 & Mysodendron & $101705-37-7$ & (Kuruüzüm-Uz et al., 2003) \\
\hline 39 & Chlorogenic acid & $327-97-9$ & (Şarer et al., 2008) \\
\hline 40 & Methylisovanilate & $6702-50-7$ & (Kuruüzüm-Uz et al., 2003) \\
\hline 41 & Methyl -3,4-dihydroxybenzoate & $99-50-3$ & (Makhmoor et al., 2010) \\
\hline
\end{tabular}




\begin{tabular}{|c|c|c|c|}
\hline \multicolumn{4}{|c|}{ Terpenoid compounds } \\
\hline 42 & Vitexilactone & $61263-49-8$ & (Hajdú et al., 2007) \\
\hline 43 & Vitexilactone B & $329763-47-5$ & (Hajdú et al., 2007) \\
\hline 44 & Vitexilactone $\mathrm{C}$ & & (Hajdú et al., 2007) \\
\hline 45 & Vitexilactone D & $351427-18-4$ & (Li et al., 2013) \\
\hline 46 & Rotundifuran & $50656-65-0$ & (Li et al., 2013) \\
\hline 47 & Spatulenol & $6750-60-3$ & (Li et al., 2013) \\
\hline 48 & 8-epi-manoyl oxide & $596-84-9$ & (Chen et al., 2011) \\
\hline 49 & Aromadendren $-4 \alpha, 10 \alpha$-diol & $70051-38-6$ & (Chen et al., 2011) \\
\hline 50 & 3-Epicorosolic acid & $52213-27-1$ & (Chen et al., 2011) \\
\hline 51 & 3-epi-maslinic acid & $26563-68-8$ & (Chen et al., 2011) \\
\hline 52 & Ilelatifol D & & (Chen et al., 2011) \\
\hline 53 & Vitexilactam A & & (Li et al., 2002) \\
\hline 54 & Vitexilactam B & & (Li et al., 2013) \\
\hline 55 & Vitexilactam C & & (Li et al., 2013) \\
\hline
\end{tabular}

Wuttke et al. (2003) conducted a study in which fractions of chaste tree extract and individual compounds were obtained using preparative chromatography, after which the ability of the eluates to dose-dependently displace labeled ligands from the dopamine receptors of cultured pituitary cells was investigated. In addition to the compounds described above, it was possible to additionally establish the structures of three bioactive substances of the labdane type and six compounds of the clerodane type. The data showed that one of the substances, clerodadienol, had the highest activity and was minimally inferior to dopamine in inhibiting the release of prolactin from pituitary cells.

In vivo experiments aimed at assessing the probable effect of chaste tree extract on male reproductive function are important for understanding its mechanism of action. To do this, male mouse groups were separately injected intraperitoneally with bromocriptine (a dopamine receptor agonist), haloperidol (a dopamine receptor blocker), chaste tree extract, or a combination of the three. The levels of luteinizing hormone and testosterone were increased with the introduction of haloperidol due to the regulatory action of dopamine but decreased in all other cases (Nasri et al., 2007). Decreases in the levels of the studied hormones due to the combined intake of chaste tree extract and haloperidol indicate the presence of additional regulatory mechanisms that are not associated with dopamine.

\section{Opioid activity}

There are reports that the endogenous opiate system is closely related to the regulation of the hypothalamic-pituitary axis. The presence of biologically active substances in chaste tree fruits potentially affects the opioid system and may account for the unique effect of this plant in females (Facchinetti et al., 1994). A study reported on the affinity of the lipophilic fractions of chaste tree fruit extract for $\mu$ - and $\kappa$-opioid receptors, with $\mathrm{IC}_{50}$ values of 36 and $22 \mu \mathrm{g} / \mathrm{ml}$, respectively (Meier et al., 2000).

Research on the effect of chaste tree fruits on the opioid system also confirmed that the petroleum, chloroform, and ethyl acetate fractions (lipophilic fractions) had affinities for the $\mu$ - and $\delta$-opioid receptors, while the aqueous fraction showed no such affinity. Among the marker substances of the studied raw material, the greatest contribution was found to be made by the flavonoid casticin, with $\mathrm{IC}_{50}$ values of $2.84 \pm 0.707$ and $2.05 \pm 0.631 \mu \mathrm{M}$ for $\mu$ - and $\delta$-opioid receptors, respectively (Webster et al., 2011).

\section{Estrogenic activity}

The results of a study by Jarry et al. (2003) indicated that the flavonoids apigenin, penduletin, and vitexin exerted estrogenic effects, with $\mathrm{IC}_{50}$ values of $0.08,0.25$, and $10 \mu \mathrm{g} / \mathrm{ml}$, respectively, while the original extract (commercial name BNO 1095) had a concentration of an inhibitor at which $50 \%$ inhibition of the response is seen $\left(\mathrm{IC}_{50}\right)$ of $10 \mu \mathrm{g} / \mathrm{ml}$. These compounds showed affinity only for the $\beta$-estrogen receptors. An additional synergistic effect of chaste tree fruits in PMS treatment may be due to the ability of the linolenic acid component to induce the expression of the $\beta$-estrogen receptor gene, as demonstrated experimentally in Ishikawa cells (Liu et al., 2004). The same study showed that the methanol extract of the chaste tree fruit displaced estrogen from the $\alpha$ - and $\beta$-estrogen receptors.

Several indirect pharmacological tests have confirmed the estrogenic activity of chaste tree fruits. Cognitive function and uterine size were studied in female ovariectomized mice (Allahtavakoli et al., 2015). In another study, the quality of bone tissue was monitored in male mice with orchiectomy (Sehmisch et al., 2009). In both studies, positive effects were observed.

A study using molecular docking has been published. The study reports that quercetin, casticin, agnuside, isovitexin, and apigenin have an affinity for the estrogen receptor (Powers et al., 2015)

\section{Immunomodulatory effects}

The immunomodulatory effect of chaste tree products has been attributed to the flavonoid casticin (Mesaik et al., 2009). It was confirmed experimentally that casticin significantly 
inhibited monocyte chemotaxis and T-lymphocyte proliferation at levels comparable to inhibition by prednisolone.

\section{Antineoplastic activity}

The cytotoxic effect of agnuside on some types of cancer cells has been confirmed via in vitro experiments, as has its effect on the nuclear condensation and apoptosis of these cells (Arokiyaraj et al., 2012). In addition, vitetrifoline D has shown high potential as an agent for cancer chemoprophylaxis (Li et al., 2013). Chaste tree alcohol extract and essential oil produced strong, dose-dependent antimutagenic effects in a genetic test (Sarac et al., 2015).

\section{Antioxidant activity}

A study by Hajdú et al. (2007) on the antioxidant effects of bioactive substances in the lipophilic hexane fraction of the aqueous-alcoholic extract of chaste tree found that the flavonoid casticin produced the strongest antioxidant activity, which was several times superior to that of ascorbic acid. Moreover, a study on the effect of chaste tree extract on iron II-mediated free radical oxidation of deoxyribose revealed that the aucubin iridoid agnuside significantly inhibited this damage (Arokiyaraj et al., 2012). An investigation that screened compounds isolated from the chaste tree for antioxidant effects through free radical neutralization using 1,1-diphenyl-2-picrylhydrazyl demonstrated that methyl 3,4-dihydroxybenzoate and 3,4-dihydroxybenzoic acid had strong antioxidant properties, while casticin and vanillic acid produced moderate effects (Makhmoor and Choudhary, 2010).

\section{Pharmacological properties of essential oil}

Essential oils often exhibit antimicrobial and antifungal effects. A study by Stojković et al. (2011) measured in vitro antimicrobial and antifungal effects (as appropriate) in terms of $\mathrm{IC}_{50}$ values with respect to Micrococcus flavus, Bacillus subtilis, Salmonella typhimurium, Staphylococcus aureus, Escherichia coli, Alternaria alternata, Aspergillus flavus, Aspergillus niger, Aspergillus ochraceus, Fusarium tricinctum, Penicillium ochrochloron, Penicillium funiculosum, and Trichoderma viride. The reference compounds were 1,8-cineole and $\alpha$-pinene, the predominant components of chaste tree essential oil. The standard drugs used were the antibacterial streptomycin and antifungal bifonazole. The Minimum inhibitory concentration (MIC) values of the essential oil against bacteria ranged from 44 to $890 \mu \mathrm{g} / \mathrm{ml}$, while the MIC ranges of 1,8-cineole, $\alpha$-pinene, and streptomycin were 4-8, 5-10, and 50-200 $\mu \mathrm{g} / \mathrm{ml}$, respectively. The MIC values of the essential oil against fungi were $45-219 \mu \mathrm{g} / \mathrm{ml}$, while those of 1,8-cineole, $\alpha$-pinene, and bifonazole were 4-7, 4-8, and 100 $250 \mu \mathrm{g} / \mathrm{ml}$, respectively. Thus, the antimicrobial and antifungal properties of chaste tree essential oil were largely due to 1,8-cineole, which was the most active component; the 1,8-cineole content of the essential oil was also more than that of the aqueous extract. In another study (Asdadi et al., 2015), the antifungal activity of the essential oil was investigated against eight Candida species, including strains that acquired drug resistance. The methods used were macrodilution (determination of minimum inhibitory and fungicidal concentration) and the agar disc-diffusion method. In an overwhelming number of tests, the effectiveness of the essential oil was higher than that of fluconazole and amphotericin
B. However, negative results were obtained in studies of the antioxidant activity of the essential oil using the 1,1-diphenyl-2picrylhydrazyl test system.

Research using several in vitro test systems (1,1-diphenyl2-picrylhydrazyl, beta-carotene/linoleic acid, and reducing power tests) has demonstrated the low antioxidant activity of chaste tree essential oil (Sarikurkcu et al., 2009). In all cases, the antioxidant activity of the essential oil was less than that of the aqueous extract obtained from the same raw material. Considering the low content of essential oil in chaste tree fruits (about $0.5 \%$ ), it can be argued that their antioxidant effect is not due to essential oil.

\section{Clinical Studies}

Clinical trials are used to assess the safety and efficacy of new treatments and are a prerequisite for bringing a drug to market and widespread use in humans. Clinical research requires a rigorous scientific approach and statistical processing of the results. Among all methods for assessing the effectiveness of a drug, the data obtained from clinical trials are the most reliable.

One of the first clinical studies of a drug based on Vitex in which 52 women participated found that the prolactin level significantly decreased, and deficiencies in the luteal phase of the menstrual cycle and the synthesis of luteal progesterone were eliminated after administering the drug for 3 months. Additionally, it was indicated that two women could become pregnant during therapy (Milewicz et al., 1993).

A preparation based on Vitex extract, Pregnoton (Russia), is used specifically to increase female fertility. In a clinical study involving 25 families who had been infertile for 1-4.5 years, 5 women could become pregnant. As in the previous study, evaluating the drug's efficacy in women revealed clear benefits. These included a decrease in prolactin levels, lengthening of the luteal phase of the menstrual cycle, normalization of the menstrual cycle, reduction of pain, and an increase in progesterone levels (Zhukov et al., 2013).

The presence of dopaminergic properties was confirmed in a clinical study in patients with severe and mild mastalgia. The therapy involved daily administration of $40 \mathrm{mg}$ of chaste tree fruit extract (Agnucaston $\AA$, Biomeks, Germany). The standard group was treated with $2.5 \mathrm{mg}$ of bromocriptine, a dopamine receptor agonist, twice a day. In both groups, there was a comparable decrease in blood prolactin levels and a significant decrease in pain in the mammary glands. Not a single case of adverse reactions was recorded in the group receiving chaste tree extract, compared with a $12.5 \%$ incidence of adverse reactions under bromocriptine treatment (Kilicdag et al., 2004). The anti-inflammatory properties of some chaste tree metabolites such as $p$-hydroxybenzoic acid, methyl 3,4-dihydroxybenzoate, and 3,4-dihydroxybenzoic acid potentially also contributed to pain relief.

In one retrospective study involving women with moderate-to-severe PMS, it was demonstrated that daily intake of $5 \mathrm{mg}$ of chaste tree extract over three menstrual cycles resulted in a significant decrease in the severity of PMS in $67 \%$ of subjects (Prilepskaya et al., 2006). The effect of chaste tree extract on cyclic mastalgia was established in a randomized, placebo-controlled, double-blind study. The long-term study demonstrated the high efficacy of chaste tree extract as early as in the second menstrual cycle, with a $53 \%$ decrease in pain intensity (Halaska et al., 1999). 
To compare the treatment effects of chaste tree extract with those of other drugs, a clinical study was conducted in which one group was treated with chaste tree extract and the other with fluoxetine, an antidepressant and serotonin reuptake inhibitor that is sometimes used for the alleviation of PMS. In patients from both groups, there were equal decreases in PMS symptoms. However, chaste tree extract influenced physiological symptoms such as breast tenderness, edema, convulsions, irritability, and increased appetite to a greater extent, while fluoxetine had a greater effect on neurological symptoms such as irritability, insomnia, depression, nervous tension, and breast pain (Atmaca et al., 2003).

A similar study in which fluoxetine was used as the standard drug showed that chaste tree-based medicine produced better results with respect to performance, depressed mood, and general somatic symptoms. Thus, the use of chaste tree preparations is preferable for alleviating the physiological manifestations of PMS (Ciotta et al., 2011).

A clinical study using dry chaste tree extract Ze 440 at a dose of $20 \mathrm{mg}$ per day demonstrated clear superiority of the drug over placebo, with $52 \%$ and $24 \%$ decreases in PMS symptoms, respectively, with no adverse reactions requiring discontinuation of the drug (Schellenberg, 2001).

In another clinical study, Agnolyt $\mathrm{P}$ capsules containing chaste tree fruit extract were used, with pyridoxine as the reference drug. Clinical improvements and a high benefit-to-risk ratio were observed in $77.1 \%$ of subjects when compared with $60.6 \%$ of the reference group (Lauritzen et al., 1997).

An important argument in favor of the safety of chaste tree-based drugs is the low frequency of occurrence of undesirable reactions. A review of clinical trials (van Die et al., 2013) indicated that, out of 641 participants, only 35 cases of side effects were recorded, with nausea and headache being the major complaints.

\section{CONCLUSION}

The chaste tree is a medicinal plant with unique pharmacological properties. Several clinical studies have demonstrated its effectiveness in PMS treatment, and the scientific community has displayed tremendous interest in the study of this plant.

Both diseases and multicomponent plant extracts affect several hormonal regulation systems. Thus, Vitex extract activates many of the major systems, including the hypothalamic-hypophyseal, opioid, and immune systems. The receptors for these systems are found in all tissues of the body, and a complex network of receptor interactions produces the necessary therapeutic effect without side effects. A systematic approach to the study of these interactions can lead to the emergence of future generations of drugs.

With regard to Vitex, the large number of pharmacological effects of its individual chemical compounds and the high pharmacological activity of the whole extract require further study to detect synergistic interactions and ways of regulating the female reproductive system. This will allow the use of new treatment methods for diseases such as PMS and female infertility.

\section{LIST OF ABBREVIATIONS}

PMS Premenstrual syndrome

IC50 Concentration of half-maximal binding

MIC Minimum inhibitory concentration

\section{CONFLICTS OF INTEREST}

The authors report no financial or any other conflicts of interest in this work.

\section{FUNDING}

There is no funding to report.

\section{ETHICAL APPROVAL}

Not applicable.

\section{AUTHOR CONTRIBUTIONS}

All authors made substantial contributions to the conception and design of the review, acquisition of data, or analysis and interpretation of data; took part in drafting the article or revising it critically for important intellectual content; agreed to submit it to the current journal; gave final approval of the version to be published; and agree to be accountable for all aspects of the work. All authors are eligible for authorship as per the requirements/guidelines of the International Committee of Medical Journal Editors (ICMJE).

\section{PUBLISHER'S NOTE}

This journal remains neutral with regard to jurisdictional claims in published institutional affiliation.

\section{REFERENCES}

Abbas Azimi R, Jamzad Z, Sefidkon F, Bakhshi-Khaniki G. The potential value of phytochemical and micromorphological characters in taxonomic treatment of genus Vitex L. (Lamiaceae). Iran J Bot, 2006; 12(1):15-35.

Aleshnikova KY, Dul VN, Dzhavakhyan MA, Semkina OA. Development and standardization of crayons with Eucalimine. Drug Dev Regist, 2020; 9(4):99-106. [In Russ.].

Allahtavakoli M, Honari N, Pourabolli I, Arababadi MK, Ghafarian $\mathrm{H}$, Roohbakhsh A, Shamsizadeh A. Vitex agnus castus extract improves learning and memory and increases the transcription of estrogen receptor $\alpha$ in hippocampus of ovariectomized rats. Basic Clin Neurosci, 2015; 6(3):185.

Arokiyaraj S, Perinbam K, Vivek P, Udaya Prakash NK. Free radical scavenging and in vitro cytotoxicity activity of agnuside from Vitex agnus castus (Verbenacae). J Pharm Res, 2012; 5(5):2548-52.

Asdadi A, Hamdouch A, Oukacha A, Moutaj R, Gharby S, Harhar H, El Hadek M, Chebli B, Idrissi Hassani LM. Study on chemical analysis, antioxidant and in vitro antifungal activities of essential oil from wild Vitex agnus-castus L. seeds growing in area of Argan Tree of Morocco against clinical strains of Candida responsible for nosocomial infections. J Mycol Med, 2015; 25(4):e118-27.

Atmaca M, Kumru S, Tezcan E. Fluoxetine versus Vitex agnus castus extract in the treatment of premenstrual dysphoric disorder. Hum Psychopharmacol Clin Exp, 2003; 18(3):191-5.

Chen SN, Friesen JB, Webster D, Nikolic D, van Breemen RB, Wang ZJ, Fong HH, Farnsworth NR, Pauli GF. Phytoconstituents from Vitex agnus-castus fruits. Fitoterapia, 2011; 82(4):528-33.

Choudhary MI; Azizuddin, Jalil S, Nawaz SA, Khan KM, Tareen RB, Atta-ur-Rahman. Antiinflammatory and lipoxygenase inhibitory compounds from Vitex agnus-castus. Phytother Res, 2009; 23(9):1336-9.

Ciotta L, Pagano I, Stracquadanio M, Di Leo S, Andò A, Formuso C. Psychic aspects of the premenstrual dysphoric disorders. New therapeutic strategies: our experience with Vitex agnus castus. Minerva Ginecol, 2011; 63(3):237-45

Facchinetti F, Fioroni L, Martignoni E, Sances G, Costa A, Genazzani AR. Changes of opioid modulation of the hypothalamo-pituitaryadrenal axis in patients with severe premenstrual syndrome. Psychosom Med, 1994; 56(5):418-22.

Fedorov AA. Flora of the European part of the USSR. V. III. Science, Leningrad, Russia, p 259, 1978. [In Russ.]. 
Flora of Pakistan. [ONLINE] Available via http://efloras.org/ florataxon.aspx?flora_id=5andtaxon_id=250064507 (Accessed 01 May 2021).

Fukahori M, Kobayashi S, Naraki Y, Sasaki T, Oka H, Seki M, Masada-Atsumi S, Hakamatsuka T, Goda Y. Quality evaluation of medicinal products and health foods containing chaste berry (Vitex agnuscastus) in Japanese, European and American markets. Chem Pharm Bull (Tokyo), 2014; 62(4):379-85.

Ghannadi A, Bagherinejad M, Abedi D, Jalali M, Absalan B, Sadeghi N. Antibacterial activity and composition of essential oils from Pelargonium graveolens L'Her and Vitex agnus-castus L. Iran J Microbiol, 2012; 4(4):171

Görler K, Oehlke D, Soicke H. Iridoidführung von Vitex agnuscastus. Planta Med, 1985; 51(06):530-1.

Hajdú Z, Hohmann J, Forgo P, Martinek T, Dervarics M, Zupkó I, Falkay G, Cossuta D, Máthé I. Diterpenoids and flavonoids from the fruits of Vitex agnus-castus and antioxidant activity of the fruit extracts and their constituents. Phytother Res, 2007; 21(4):391-4.

Halaska M, Beles P, Gorkow C, Sieder C. Treatment of cyclical mastalgia with a solution containing a Vitex agnus castus extract: results of a placebo-controlled double-blind study. Breast, 1999; 8(4):175-81.

Hoberg E, Orjala J, Meier B, Sticher O. Diterpenoids from the fruits of Vitex agnus-castus. Phytochemistry, 1999; 52(8):1555-8.

Jarry H, Spengler B, Porzel A, Schmidt J, Wuttke W, Christoffel $\mathrm{V}$. Evidence for estrogen receptor $\beta$-selective activity of Vitex agnus-castus and isolated flavones. Planta Med, 2003; 69(10):945-7.

Karaguzel O, Girmen B. Morphological variations of chaste tree (Vitex agnus-castus) genotypes from southern Anatolia, Turkey. N Z J Crop Hortic Sci, 2009; 37(3):253-61.

Kilicdag EB, Tarim E, Bagis T, Erkanli S, Aslan E, Ozsahin $\mathrm{K}$, Kuscu E. Fructus agni casti and bromocriptine for treatment of hyperprolactinemia and mastalgia. Int J Gynecol Obstet, 2004; 85(3):292-3.

Kuruüzüm-Uz A, Ströch K, Demirezer LÖ, Zeeck A. Glucosides from Vitex agnus-castus. Phytochemistry, 2003; 63(8):959-64.

Lauritzen CH, Reuter HD, Repges R, Böhnert KJ, Schmidt U. Treatment of premenstrual tension syndrome with Vitex agnus castus controlled, double-blind study versus pyridoxine. Phytomedicine, 1997; 4(3):183-9.

Li S, Qiu S, Yao P, Sun H, Fong HH, Zhang H. Compounds from the fruits of the popular European medicinal plant Vitex agnus-castus in chemoprevention via NADP $(\mathrm{H})$ : quinone oxidoreductase type 1 induction. Evid Based Complement Alternat Med, 2013; 2013:432829.

Li SH, Zhang HJ, Qiu SX, Niu XM, Santarsiero BD, Mesecar AD, Fong HH, Farnsworth NR, Sun HD. Vitexlactam A, a novel labdane diterpene lactam from the fruits of Vitex agnus-castus. Tetrahedron Lett, 2002; 43(29):5131-4.

Liu J, Burdette JE, Sun Y, Deng S, Schlecht SM, Zheng W, Nikolic D, Mahady G, Van Breemen RB, Fong HH, Pezzuto JM. Isolation of linoleic acid as an estrogenic compound from the fruits of Vitex agnuscastus L. (chaste-berry). Phytomedicine, 2004; 11(1):18-23.

Makhmoor T, Choudhary MI. Radical scavenging potential of compounds isolated from Vitex agnus-castus. Turk J Chem, 2010; 34(1):119-26.

Mammadova IO, Mammadova ZA. Study of the introduction, morphological features and reproduction of Vitex agnus-castus L. under absheron conditions. Bull Sci Pract, 2019; 5(5):31-7. [In Russ.].

Mari A, Montoro P, D’Urso G, Macchia M, Pizza C, Piacente S. Metabolic profiling of Vitex agnus castus leaves, fruits and sprouts: analysis by LC/ESI/(QqQ) MS and (HR) LC/ESI/(Orbitrap)/MSn. J Pharm Biomed Anal, 2015; 102:215-21.

Meier B, Berger D, Hoberg E, Sticher O, Schaffner W. Pharmacological activities of Vitex agnus-castus extracts in vitro. Phytomedicine, 2000; 7(5):373-81.

Milewicz A, Gejdel E, Sworen H, Sienkiewicz K, Jedrzejak J, Teucher T, Schmitz H. Vitex agnus castus extract in the treatment of luteal phase defects due to latent hyperprolactinemia. Results of a randomized placebo-controlled double-blind study. Arzneimittel-forschung, 1993; 43(7):752-6.
Mesaik MA, Azizuddin, Murad S, Khan KM, Tareen RB, Ahmed A, Atta-ur-Rahman, Choudhary MI. Isolation and immunomodulatory properties of a flavonoid, casticin from Vitex agnus-castus. Phytother Res, 2009; 23(11):1516-20.

Nadkarni KM, Nadkarni AK. Indian Materia Medica. Dhoot Papeshwar Prakashan Ltd, Bombay, India, p 1319, 1954.

Nasri S, Oryan S, Rohani AH, Amin GR. The effects of Vitex agnus castus extract and its interaction with dopaminergic system on LH and testosterone in male mice. Pak J Biol Sci, 2007; 10(14):2300.

Palvinskiy AG, Bakhrushina EO, Kozlova ZM, Sinitsyna AA, Krasnyuk II. Development of thermoreversible dental gel with berberine. Drug Dev Regist, 2020; 9(4):88-92. [In Russ.].

Pisarev DI, Novikov OO, Zhilyakova ET, Boyko NN, Abramovich RA, Potanina OG, Lazar S, Ahmad AS, Nasser R. Development of the composition and technology of a granular dosage form based on a thick milk thistle extract and ademetionine. Drug Dev Regist, 2020; 9(2):106-12. [In Russ.].

Powers CN, Setzer WN. A molecular docking study of phytochemical estrogen mimics from dietary herbal supplements. In Silico Pharmacol, 2015; 3(1):1-63.

Prilepskaya VN, Ledina AV, Tagiyeva AV, Revazova FS. Vitex agnus castus: successful treatment of moderate to severe premenstrual syndrome. Maturitas, 2006; 55:55-63.

Rafieian-Kopaei M, Movahedi M. Systematic review of premenstrual, postmenstrual and infertility disorders of Vitex agnus castus. Electron Physician, 2017; 9(1):3685.

Rogozhnikova EP, Mizina PG, Mardanly SG. Effect of different extractant concentrations on the content of biologically active substances in motherwort tincture. Drug Dev Regist, 2020; 9(4):72-8. [In Russ.].

Salehpour Z, Jahantab E, Morshedloo MR, Iraji A, Mohamadi J. Essential oil composition of aerial parts of Vitex pseudo-negundo populations collected from Southwest of Iran. J Essential Oil Bear Plants, 2018; 21(2):570-6.

Sarac N, Ugur A, Sen B. In vitro antimutagenic activity of Vitex agnus-castus L. essential oils and ethanolic extracts. Ind Crops Prod, 2015; 63:100-3.

Sarer E, Gökbulut A. Determination of caffeic and chlorogenic acids in the leaves and fruits of Vitex agnus-castus. Turk J Pharm Sci, 2008; 5(3):167-74.

Sarikurkcu C, Arisoy K, Tepe B, Cakir A, Abali G, Mete E. Studies on the antioxidant activity of essential oil and different solvent extracts of Vitex agnus castus L. fruits from Turkey. Food Chem Toxicol, 2009; 47(10):2479-83.

Schellenberg R. Treatment for the premenstrual syndrome with agnus castus fruit extract: prospective, randomised, placebo controlled study. Br Med J, 2001; 322(7279):134-7.

Sehmisch S, Boeckhoff J, Wille J, Seidlova-Wuttke D, Rack T, Tezval M, Wuttke W, Stuermer KM, Stuermer EK. Vitex agnus castus as prophylaxis for osteopenia after orchidectomy in rats compared with estradiol and testosterone supplementation. Phytother Res, 2009; 23(6):851-8.

Sliutz G, Speiser P, Schultz AM, Spona J, Zeillinger R. Agnus castus extracts inhibit prolactin secretion of rat pituitary cells. Horm Metab Res, 1993; 25(05):253-5.

Sogame M, Naraki Y, Sasaki T, Seki M, Yokota K, Masada S, Hakamatsuka T. Quality assessment of medicinal product and dietary supplements containing Vitex agnus-castus by HPLC fingerprint and quantitative analyses. Chem Pharm Bull, 2019; 67(6):527-33.

Sorensen JM, Katsiotis ST. Parameters influencing the yield and composition of the essential oil from Cretan Vitex agnus-castus fruits. Planta Med, 2000; 66(03):245-50.

Sorensen JM, Katsiotis ST. Variation in essential oil yield and composition of Cretan Vitex agnus castus L. fruits. J Essential Oil Res, 1999; 11(5):599-605.

Stojković D, Soković M, Glamočlija J, Džamić A, Ćirić A, Ristić M, Grubišić D. Chemical composition and antimicrobial activity of Vitex agnus-castus L. fruits and leaves essential oils. Food Chem, 2011; 128(4):1017-22. 
ThePlantList. [ONLINE] 2013. Available via http://www. plantlist.org/tpl1.1/search?q=Vitex (Accessed 01 May 2021).

United States Department of Agriculture. Vitex agnuscastus L. [ONLINE] 2021. Available via https://plants.usda.gov/home/ plantProfile?symbol=VIAG (Accessed 01 May 2021).

van Die MD, Burger HG, Teede HJ, Bone KM. Vitex agnuscastus extracts for female reproductive disorders: a systematic review of clinical trials. Planta Med, 2013; 79(07):562-75.

Webster DE, He Y, Chen SN, Pauli GF, Farnsworth NR, Wang ZJ. Opioidergic mechanisms underlying the actions of Vitex agnus-castus $\mathrm{L}$. Biochem Pharmacol, 2011; 81(1):170-7.

Wuttke W, Jarry H, Christoffel V, Spengler B, Seidlová-Wuttke D. Chaste tree (Vitex agnus-castus)-pharmacology and clinical indications. Phytomedicine, 2003; 10(4):348-57.
Zhukov OB, Evdokimov VV, Zhukov AA, Shugusheva LK, Bragina EE. A new strategy for medical support of a married couple in infertility. Androl Genital Surg, 2013; 2:74-81. [In Russ.].

\section{How to cite this article:}

Adamov GV, Rendyuk TD, Saybel OL, Dargaeva TD, Tsitsilin AN, Bokov DO. Vitex agnus-castus: Botanical features and area, chemical composition of fruit, pharmacological properties, and medicinal uses. J Appl Pharm Sci, 2022; 12(03):034-044. 